Journal of

Innate Immunity
Editorial

J Innate Immun 2020;12:355-356

DOI: $10.1159 / 000510316$
Received: July 19, 2020

Accepted: July 19, 2020

Published online: August 20, 2020

\title{
A Leak in the Dike
}

In the 19th century poem A Leak in the Dyke by the American writer Phoebe Cary, a young Dutch boy saves his community by jamming a finger into a leaking levee, illustrating the importance of barrier integrity but also the need of supportive measures. A similar view on epithelial linings as simple physical barriers of the body is often taken, but in recent decades, a broad spectrum of dynamic functions has been described for the epithelial cells. These include chemokine production to recruit immune cells, synthesis of antibacterial molecules, and interaction with the adaptive immune system during immunization [1-4]. In this issue, Carl Persson [5] takes a thought-provoking and maybe unorthodox viewpoint on host defense at the mucosal surfaces in his review. He discusses the importance of non-sieved plasma proteins/ peptides at the surface of intact mucosal barriers in vivo. These proteins, including antimicrobial proteins, are likely to play important roles in host defense.

Often adjacent to the mucosal lining, macrophages display a large plasticity and can be divided into numerous subsets that often are tissue specific where they exert broad sets of functions [6-10]. In an experimental study, van Riet et al. [11] show that subsets, i.e., M(GM-CS) and $\mathrm{M}(\mathrm{M}-\mathrm{CSF})$ macrophages, respectively, play different roles during inflammation, enhancing epithelial innate immunity and wound repair to different extents. Macrophages are important gatekeepers and recognize intruding pathogens at an early stage. TLR9 is localized in their endosomes, acting as a sensor for unmethylated CpG motifs that are present in bacteria, DNA viruses (e.g., HSV1 ), and fungi. In an important study presented in this issue, Zyzak et al. [12] show that the MyD88 adapter-like
(Mal) adapter molecule, considered important for recognition of bacteria through TLR2- and TLR4-dependent pathways, is engaged in TLR9-dependent expression of genes encoding IFN $\beta$ and TNFa in macrophages infected by Herpes simplex.

Another important cell in proximity of epithelial linings is the mast cell, commonly associated with its content and release of histamine and heparin but also a broad set of immunoregulatory functions through production of cytokines and eicosanoids. It has become evident that mast cell proteases play important roles in the immunobiology of mast cells and their roles in disease. In an intriguing review, Gunnar Pejler [13] provides an overview of the current understanding of mast cell chymase. Mucosal-associated invariant T (MAIT) cells are getting increasing attention as they produce proinflammatory cytokines in an innate-like manner and play an important role in controlling the host immune response [14]. Inflammatory bowel disease, particularly in the case of ulcerative colitis, is characterized by mucosal inflammation. Ju et al. [15] found that circulating MAIT cell levels were reduced in these patients. Furthermore, MAIT cell deficiency was correlated with disease activity, and their state of activation was increased. Taken together, this suggests important roles for MAIT cells in inflammatory bowel disease.

In conclusion, this issue mainly focuses on the mucosa and cells in its neighborhood. We hope that the articles will provide interesting reading to the readership of the journal!

Arne Egesten, Lund Heiko Herwald, Lund karger@karger.com

www.karger.com/jin

Karger"
(C) 2020 The Author(s)

Published by S. Karger AG, Basel

Karger
Open access

This is an Open Access article licensed under the Creative Commons Attribution-NonCommercial-4.0 International License (CC BY-NC) (http://www.karger.com/Services/OpenAccessLicense), applicable to the online version of the article only. Usage and distribution for commercial purposes requires written permission. 


\section{Conflict of Interest Statement}

The authors declare no conflicts of interest.

\section{Funding Sources}

No external funding was associated with this editorial.

\section{References}

1 Rhen M. Salmonella and Reactive Oxygen Species: A Love-Hate Relationship. J Innate Immun. 2019;11(3):216-26.

2 Onyiah JC, Schaefer REM, Colgan SP. A Central Role for Heme Oxygenase-1 in the Control of Intestinal Epithelial Chemokine Expression. J Innate Immun. 2018;10(3):22838.

3 Hartl D, Tirouvanziam R, Laval J, Greene CM, Habiel D, Sharma L, et al. Innate Immunity of the Lung: From Basic Mechanisms to Translational Medicine. J Innate Immun. 2018;10(5-6):487-501.

4 Takaki H, Ichimiya S, Matsumoto M, Seya T. Mucosal Immune Response in Nasal-Associated Lymphoid Tissue upon Intranasal Administration by Adjuvants. J Innate Immun. 2018;10(5-6):515-21.

5 Persson C. Humoral First-Line Mucosal Innate Defence in vivo. J Innate Immun. 2020 Mar;1-14. Epub ahead of print.

6 Zulu MZ, Martinez FO, Gordon S, Gray CM. The Elusive Role of Placental Macrophages: The Hofbauer Cell. J Innate Immun. 2019; 11(6):447-56
7 Grahnert A, Weiss R, Schilling E, Stanslowsky N, Sack U, Hauschildt S. CD14 Counterregulates Lipopolysacharide-Induced Tumor Necrosis Factor- $\alpha$ Production in a Macrophage Subset. J Innate Immun. 2019;11(4):359-74.

8 Oppong-Nonterah GO, Lakhdari O, Yamamura A, Hoffman HM, Prince LS. TLR Activation Alters Bone Marrow-Derived Macrophage Differentiation. J Innate Immun. 2019; 11(1):99-108

9 Doster RS, Rogers LM, Gaddy JA, Aronoff DM. Macrophage Extracellular Traps: A Scoping Review. J Innate Immun. 2018;10(1): 3-13.

10 Gresnigt MS, Becker KL, Leenders F, Alonso MF, Wang X, Meis JF, et al. Differential Kinetics of Aspergillus nidulans and Aspergillus fumigatus Phagocytosis. J Innate Immun. 2018; 10(2):145-60

11 van Riet S, van Schadewijk A, de Vos S, Vandeghinste N, Rottier RJ, Stolk J, et al. Modulation of Airway Epithelial Innate Immunity and Wound Repair by M(GM-CSF) and M(M-CSF) Macrophages. J Innate Immun. 2020 Apr;1-12. Epub ahead of print.
12 Zyzak J, Mitkiewicz M, Leszczyńska E, Reniewicz P, Moynagh PN, Siednienko J. HSV-1/ TLR9-Mediated IFN $\beta$ and TNFa Induction Is Mal-Dependent in Macrophages. J Innate Immun. 2019 Dec;1-12. Epub ahead of print.

13 Pejler G. Novel Insight into the in vivo Function of Mast Cell Chymase: Lessons from Knockouts and Inhibitors. J Innate Immun. 2020 Jun;1-16. Epub ahead of print.

14 Jo YG, Jin HM, Cho YN, Kim JC, Kee SJ, Park YW. Activation and Impaired Tumor Necrosis Factor- $\alpha$ Production of Circulating Mucosal-Associated Invariant $\mathrm{T}$ Cells in Patients with Trauma. J Innate Immun. 2019;11(6): 506-15.

15 Ju JK, Cho YN, Park KJ, Kwak HD, Jin HM, Park SY, et al. Activation, Deficiency, and Reduced IFN- $\gamma$ Production of Mucosal-Associated Invariant $\mathrm{T}$ Cells in Patients with Inflammatory Bowel Disease. J Innate Immun. 2020 Jun;1-12. Epub ahead of print. 